\title{
Genetic and morphometric differentiation among sympatric spawning stocks of whitefish (Coregonus lavaretus L.) in Lake Femund, Norway
}

\author{
Tor F. NÆSJE*, Jukka A. VUORINEN ${ }^{1)}$ and Odd T. SANDLUND \\ Norwegian Institute for Nature Research, Tungasletta 2, NO-7485 Trondheim, Norway \\ ${ }^{1)}$ Department of Biology, University of Joensuu, P.O. Box 111, FIN-80101 Joensuu, Finland \\ *e-mail corresponding author: tor.naesje@nina.no \\ present address: South African Institute for Aquatic Biodiversity (SAIAB), Somerset Street, Private Bag 1015, Grahamstown 6140, \\ South Africa
}

\begin{abstract}
Lake Femund, Norway, contains several sympatric ecotypes of whitefish, Coregonus lavaretus L. Deepwater whitefish, river whitefish, and shallow water whitefish can be easily distinguished by spawning habitat and gillraker number. Variation in morphological and ecological characters and allozyme loci from 11 different spawning sites was analysed to compare the ecological polymorphism with possible genetic sub-structuring of whitefish in the lake. Of the individual morphological and ecological characters, gillraker number best separated the spawning populations, followed by body length. In a hierarchical cluster analysis based on gillraker number, body length and age of fish, the four deepwater sites grouped together as well as the three samples from, or closely related to, inlet rivers. The shallow water sites, however, were more dispersed. In the allozyme analysis, nine of the 38 enzyme loci were polymorphic at the 0.95 level. The amount of genetic variation was quite similar among localities with $H_{\text {exp }}=0.046-0.066$. Allele frequencies differed significantly among localities at all polymorphic loci indicating distinct reproductive isolation between spawning sites. A consensus tree based on genetic distances grouped samples according to spawning depth and trophic morphology rather than regional proximity. All deepwater spawners grouped together with rather high support while geographically adjacent samples differing by their morphology or behaviour were dispersed. The patterns of differentiation based on allozyme variation and morphology are not fully concordant, but still the association between genetic differentiation and morphological and life history variables was highly significant. Thus, the morphological differences are not due to phenotypic plasticity within single spawning populations as is commonly seen in many other fish species. The possible evolutionary origins of reproductively isolated whitefish forms are discussed. The relatively close association between differences in gillraker counts and genetic difference indicates that the present management of Femund whitefish stocks based on gillraker counts is sensible.
\end{abstract}

Key words: Coregonus, whitefish, genetic stocks, allozymes, sympatric populations, speciation

\section{INTRODUCTION}

North temperate salmonid fishes are known to occur as sympatric forms, differing in their morphology and life history characters. At least a part of this diversity has evolved after the last glaciation (Bernatchez et al. 1999; Hansen et al. 1999). Due to their short evolutionary history, these sympatric forms represent a potential to study speciation in its early stages (Bernatchez \& Wilson 1998; Bernatchez 2004). Usually sympatric forms occur as "species pairs" but in some cases four to six sympatric forms can be distinguished (Sandlund et al. 1992; Schluter 1996; Turgeon et al. 1999; Sendek 2004).

Three evolutionary non-exclusive scenarios have been proposed to explain this diversity. Firstly, the forms may simply represent phenotypic plasticity within single spawning population. Phenotypic differentiation may arise in response to variable feeding environments during ontogeny (Hindar \& Jonsson 1993; Skúlason \& Smith 1995). Secondly, the forms may also have diverged in allopatry, subsequently invading the same lake. After double or multiple invasions the forms have been able to maintain their differences (Svärdson 1979; Hindar 1994; Bernatchez et al. 1996).
The third scenario is that the forms have developed in sympatry, as has been documented in other species (Hindar \& Jonsson 1993; Taylor \& Bentzen 1993; Schluter 1996; Lu \& Bernatchez 1999; Saint-Laurent et al. 2003). It has been argued that competition could be the diversifying force through which character release can lead to differentiation in the absence of other closely related species (Robinson \& Wilson 1994; Bernatchez et al. 1999).

Genetic differentiation among sympatric populations has been documented in many salmonid species, for example in Arctic charr Salvelinus alpinus (L.) (Hindar et al. 1986; Magnusson \& Ferguson 1987), brown trout Salmo trutta L. (Ryman et al. 1979; Ferguson \& Taggart 1991), Atlantic salmon Salmo salar L. (Claytor \& Verspoor 1991; Birt et al. 1991), and lake whitefish Coregonus clupeaformis (Mitchill) (Kirkpatrick \& Selander 1979; Bodaly et al. 1992; Vuorinen et al. 1993; Bernatchez et al. 1996; Bernatchez et al. 1999).

In whitefish (Coregonus lavaretus L.), several sympatric forms are often recognized, and management and exploitation is often based on the characterization of forms based on the number of gillrakers (Svärdson 1979; Sandlund \& Næsje 1989; Sandlund et 
al. 2002). Although this species is known to often utilize many different spawning environments within lakes, the specific population structure underlying the distribution of gillraker counts within lakes has rarely been analyzed.

The aim of the present paper is to analyze the genetic differentiation among different spawning populations of whitefish in Lake Femund, southeastern Norway, and to compare the genetic differences with differences in gillraker counts and spawning site environments. The results will be discussed in relation to possible evolutionary origins of the whitefish forms, and in relation to management of the whitefish of the lake.

\section{STUDY AREA}

Lake Femund (662 $\mathrm{m}$ a.s.1., $62^{\circ} 0^{\prime} \mathrm{N} 11^{\circ} 55^{\prime} \mathrm{E}$ ) is the second largest natural lake in Norway with a surface area of $204 \mathrm{~km}^{2}$ (Fig. 1). It has two main basins with maximum depths of 134 and 90 meters, respectively. However, more than half of the lake is less than $20 \mathrm{~m}$ due to large shallow bays. Lake Femund is the uppermost major lake in the catchment area of Klara River, which drains southeast into Lake Vänern in Sweden. The lake is ultraoligotrophic. Løvik \& Kjellberg (1982) and Sandlund \& Næsje (1989) give more detailed information on the lake.

In addition to whitefish, there are seven other fish species in Lake Femund: Arctic charr (Salvelinus alpinus (L.)), brown trout (Salmo trutta L.), grayling (Thymallus thymallus (L.)), pike (Esox lucius L.), perch (Perca fluviatilis L.), burbot (Lota lota (L.)), and minnow (Phoxinus phoxinus (L.)). There have been no fish introductions into the lake. Traditionally, the exploitation of fish has been low and focused on whitefish, Arctic charr, brown trout and pike (Sandlund 1986). In 1981 a commercial whitefish fishery was initiated by local communities and a close monitoring of the fish populations was started (Sandlund \& Næsje 1989; Næsje et al. 1992; Sandlund et al. 2004). The yearly catches of whitefish have varied from 22 to less than 10 metric tons (Ugedal et al. 2002).

Based on body size and spawning sites, local fishermen have recognized up to six whitefish forms in Lake Femund (Sandlund \& Næsje 1986). The whitefish population in the lake has earlier been studied by Svärdson (1979), and based on gillraker numbers he differentiated only three forms. These forms were in accordance with his species definitions of "sandsik" with 26-29 gillrakers and adult body size up to $40 \mathrm{~cm}$, "planktonsik" with 43-47 gillrakers and adult body size from 40 to $55 \mathrm{~cm}$, and "blåsik" with 32-38 gillrakers and adult body size from 35 to $45 \mathrm{~cm}$. Gillraker distribution from survey and commercial net catches confirmed his observation of a trimodal distribution (Fig. 2). Based on gillraker number and spawning habitat, three forms of whitefish have been defined for management purposes (Tab. 1). Deepwater whitefish (D) have a modal gillraker number of 28 and spawning grounds are deeper than $30 \mathrm{~m}$, river whitefish (R) have a modal gillraker count of 36 and they spawn in inlet rivers and in or close to the mouth of the outlet river. Shallow water whitefish (S) have the highest gillraker count with a mode of 43 . They spawn at depths of $2-5$ $\mathrm{m}$. When we group the fish this way, the forms differ clearly by their growth and age at sexual maturity (Næsje et al. 1998). Nevertheless, the length variation of sexually mature fish indicates that the groups based on gillraker counts are not homogeneous.

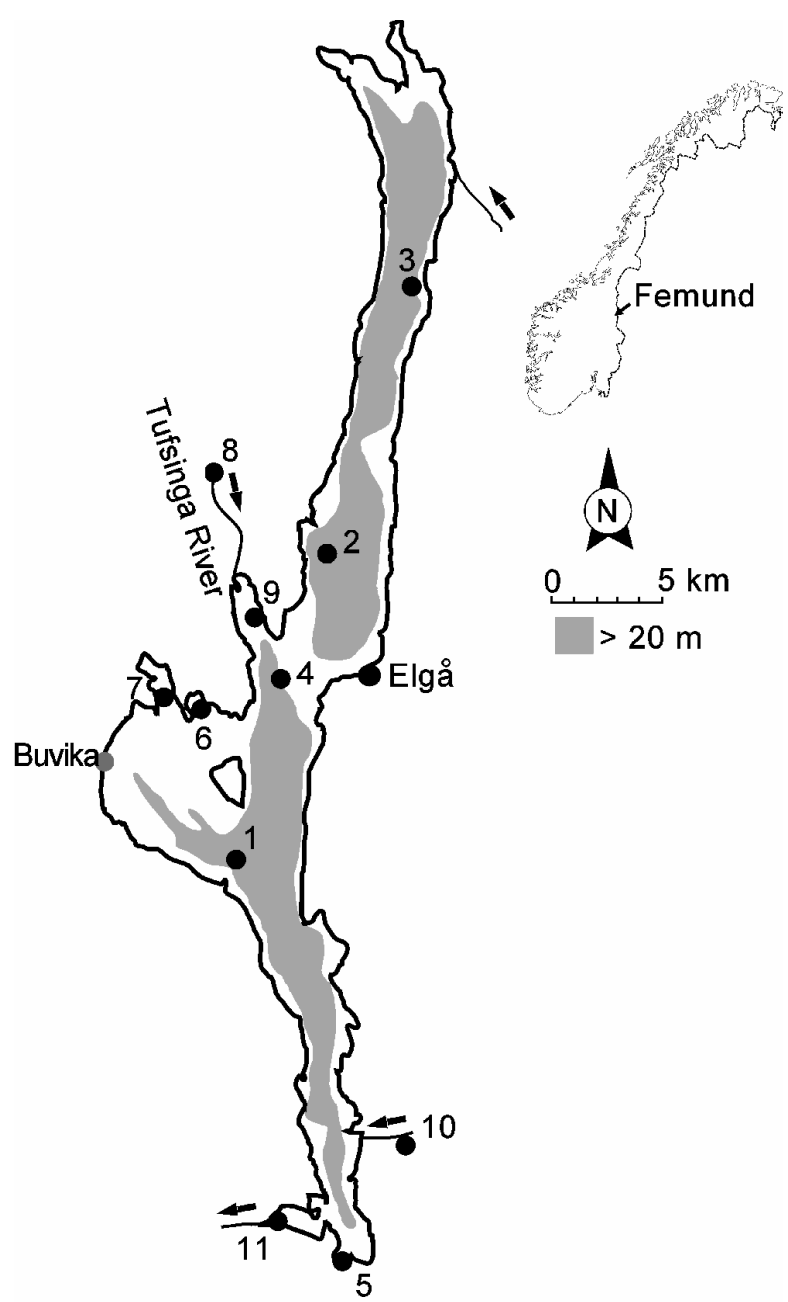

Fig. 1. The location of Lake Femund with the 11 spawning sites where whitefish were sampled. See also table 2.

\section{METHODS}

\subsection{Collection of samples}

In 1987 and 1988, 624 adult whitefish were obtained from 11 spawning sites throughout Lake Femund (Fig. 1, Tab. 2). The selection of sampling sites was based on the size of the spawning fish as well as on the physical environment of the site. 


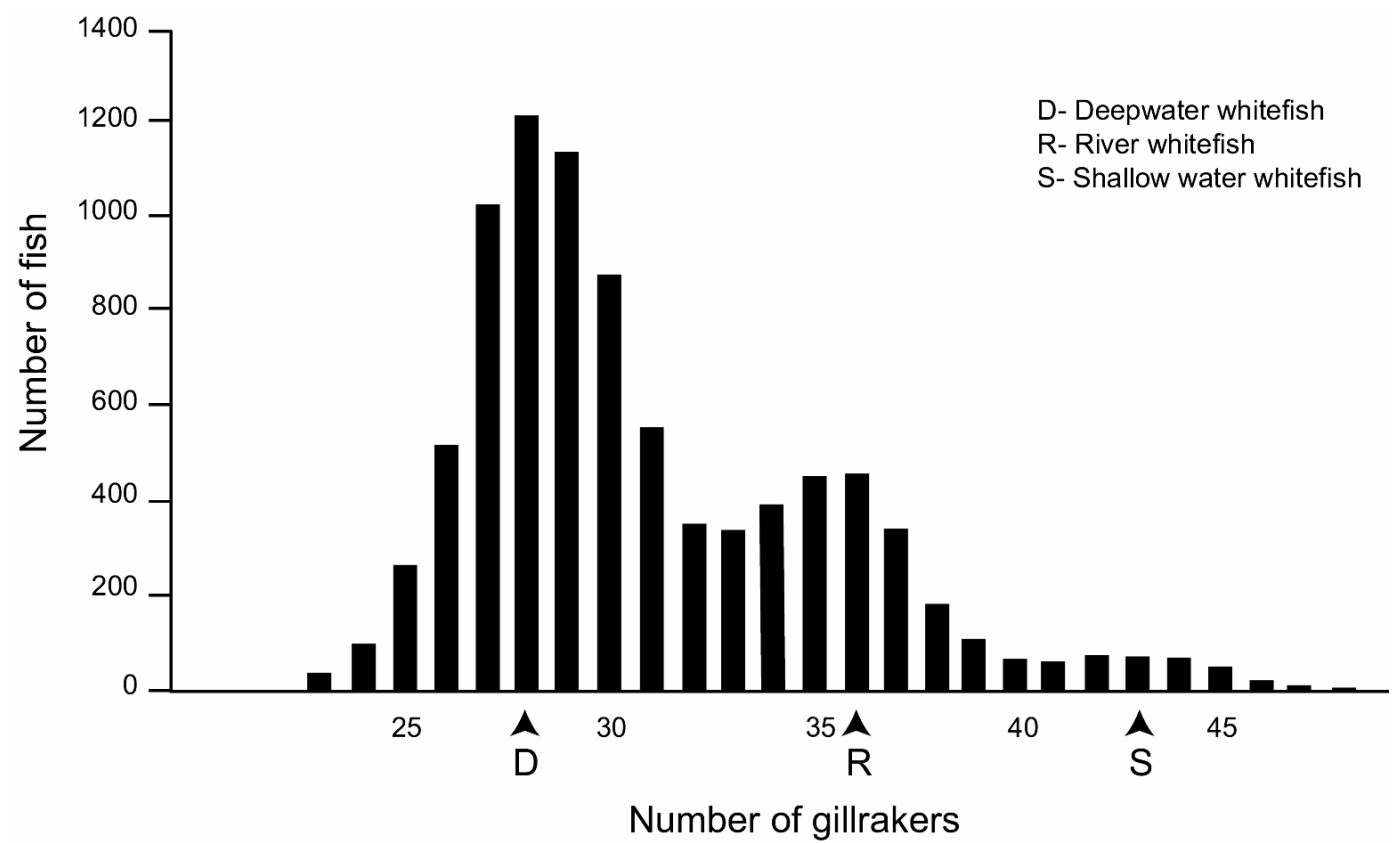

Fig. 2. Frequency distribution of gillraker counts among 8955 mature whitefish from survey and commercial net catches. D, R, and $S$ whitefish indicate the modal gillraker numbers of the whitefish forms (cf. table 1).

Tab. 1. Characteristics of whitefish forms in Lake Femund. The forms are defined based on the threemodal distribution of gillraker counts among mature fish caught in survey nets (see Fig. 2). Van Bertallanfy growth parameters are from Sandlund \& Næsje (1989).

\begin{tabular}{lccc}
\hline & Deepwater whitefish (D) & River whitefish (R) & Shallow water whitefish (S) \\
\hline Modal gillraker count & 28 & 36 & 43 \\
$\quad$ Range & $23-33$ & $34-40$ & $41-50$ \\
Length of mature fish (cm) & & & \\
$\quad$ Mean & 30.7 & 33.8 & 35.6 \\
$\quad$ Range & $20.4-46.0$ & $21.0-45.5$ & $21.4-47.5$ \\
van Bertallanfy growth parameters & & & \\
$\quad$ L (cm) & 32.2 & 38.3 & 40.5 \\
k (Brody's growth coeff.) & 0.39 & 0.26 & 0.26 \\
$\mathrm{t}_{0}$ & 2.10 & 0.42 & -0.77 \\
\hline
\end{tabular}

Tab. 2. Spawning habitat, depth of spawning and spawning time of whitefish in Lake Femund in 1987 and 1988. For reference of spawning site no. see Figure 1. Ecotype is the a priori grouping according to spawning habitat, depth and time (see text).

\begin{tabular}{|c|c|c|c|c|c|c|}
\hline Site no. & Name & Spawning habitat & Depth (m) & Spawning time & Ecotype & No of fish sampled \\
\hline 1 & Joneset & lake & 35 & November & I & 42 \\
\hline 2 & Hullet & lake & 60 & November & I & 60 \\
\hline 3 & Storvika & lake & $30-40$ & November & I & 49 \\
\hline 4 & Vestfjorden & lake & 30 & November & I & 61 \\
\hline 5 & Femundsvika & lake & $2-5$ & November & II & 53 \\
\hline 6 & Hallsteinvika & lake & $4-5$ & November & II & 37 \\
\hline 7 & Kvernvika & lake & $2-4$ & October & II & 78 \\
\hline 8 & Tufsinga & inlet river & $0.5-2$ & October & III & 91 \\
\hline 9 & Tjønnan & lake/river delta & $2-4$ & October & III & 60 \\
\hline 10 & Sorkelva & inlet river & $0.5-2$ & October & III & 40 \\
\hline 11 & Gløtfossen & lake/river outlet & $2-5$ & October & III & 77 \\
\hline
\end{tabular}


Four of the locations ( 1 to 4$)$ were in deep water ( $>30 \mathrm{~m}$ depth), three $(5,6$, and 7$)$ were in shallow water in the lake ( $<10 \mathrm{~m}$ depth), two were in inlet rivers (8 and 10), and one site was next to the outlet river (11). Location no. 9 in shallow water was in the delta formed by the inlet River Tufsinga, where spawning site 8 was situated. For subsequent analyses populations were grouped a priori into three ecotypes based on the spawning habitat, depth and time (for details, see table 2). Ecotype I (sites 1-4) spawns in over 30 m depth, ecotype II (sites 5-7) spawns at $2-5$ $\mathrm{m}$ depth in the lake, and ecotype III (sites 8-11) spawns at $0.5-5 \mathrm{~m}$ depth in or close to rivers. The ecotypes correspond roughly to the grouping applied in management (cf. Fig. 2 and Tab. 1).

During September-December spawning whitefish were sampled with gillnets with 8 mesh sizes varying from 19 to $52 \mathrm{~mm}$. Only fish with running sex products or fish which had been spawning just before their capture were included in the analyses. Sample sizes varied from 37 to 91 fish (Tab. 2). The total body length of each fish was measured. Gillrakers were counted from the anterior left gill arch. Fish were aged from otoliths, which were burned, broken and read under a stereo microscope (Skurdal et al. 1985). In addition, sex and sexual maturity were recorded.

\subsection{Morphological and ecological analyses}

Two morphological characters (mean gillraker number, mean length) and mean age of the fish samples from the 11 spawning populations were analysed by means of the hierarchical cluster analysis of the SPSS 8.0.1 software package. Depth and month of spawning were also included in a separate analysis. The variables were standardized by the z-scores function, squared Euclidian distances were calculated for pairs of populations, and the populations combined through stepwise clustering. The results are presented as a dendrogram.

\subsection{Allozyme analysis}

Whole frozen whitefish were transported to Joensuu, Finland, where they were stored at $-20{ }^{\circ} \mathrm{C}$ for a maximum of four months. Allozyme electrophoresis was used to study genetic variation within and between 11 spawning sites. Laboratory techniques are detailed in Vuorinen (1984) and Bodaly et al. (1991). The products of 38 allozyme loci were resolved from muscle, liver or eye tissue. The loci listed in Bodaly et al. (1991) were augmented with a malate dehydrogenase locus $\left(m M D H^{*}\right)$ from muscle. Isozyme banding patterns and their genetic interpretations were described in Vuorinen (1984) and Vuorinen \& Piironen (1984). The equivalence between the former nomenclature and the current standard for fish (Shaklee et al. 1990) was given in Bodaly et al. (1991). At most loci the correspondence between a particular phenotype to only one genotype is obvious and allozyme frequencies were estimated from genotype counts. This was not possible for the duplicated isoloci, which are common to all salmonids as a result of their tetraploid ancestry. The isoloci share alleles with identical electrophoretic mobility and there is no direct way to assign the variation to a particular locus of the pair. At $S A A T-1,2 *$ and $s M D H-A 1,2 *$ the variation was scarce and explicable by only one variable locus. According to a conservative approach all allelic variation was therefore assigned to one locus. For the highly variable $s M D H$ $B 1,2 *$ isoloci, allele frequencies were individually estimated for both loci by using the maximum likelihood approach of Waples (1988).

Two genetic variability measures were calculated: average heterozygosity $\left(\mathrm{H}_{\mathrm{exp}}\right)$ based on HardyWeinberg expectations, and percentage of polymorphic loci using $95 \%$ criterion, i.e. a locus was considered polymorphic if the frequency of the most common allele did not exceed $0.95\left(\mathrm{P}_{0.95 \text { crit }}\right)$.

To test for random mating within each spawning site, possible departures of observed genotype frequencies from Hardy-Weinberg equilibrium were estimated by $\chi^{2}$ tests with adjusted probability levels following Lessios (1992). These tests were not applied to $s M D H B 1,2 *$ isoloci because their locus-specific genotype information was lacking. To demonstrate the existence of multiple genetic stocks of whitefish in Lake Femund, a contingency $\chi^{2}$ test was made first among all collections and then within the three ecotypes. To further describe the extent of differentiation within and among sub-groupings, a hierarchical gene diversity analysis was performed according to the method outlined by Wright (1978). To eliminate problems of combining $\mathrm{F}_{\mathrm{ST}}$ estimates over multiple alleles at a locus (Weir \& Cockerham 1984) all polymorphisms were treated as diallelic by joining alleles at $G 3 P D H-3 *(* 70+* 65)$ and $s M D H-B 1,2 *(* 100+$ $* 90)$. F $_{\text {ST }}$ values were calculated with the BIOSYS-1 program of Swofford \& Selander (1981) and included the correction for sampling error.

To illustrate the genetic relationships among spawning locations, a consensus tree was constructed. Allozyme data was first transformed into arc distances (Cavalli-Sforza \& Edwards 1967), and neighbour joining was used to infer the tree. Vendace, Coregonus albula (L.), was used as the outgroup. The confidence of the tree topology was evaluated by generating 1,000 bootstrapped allele frequency matrices and making a consensus tree from the resulting dendrograms. Resampling was done with the BOOTDIST program of BIOSYS-2 (Black 1997) and the consensus tree was constructed with NEIGHBOR, CONSENSE and DRAWGRAM of the PHYLIP package (Felsenstein 1993).

To test for isolation-by-distance model, the relationship between genetic and geographic distances was 
Tab. 3. Mean gill raker count, body length, and age of fish sampled at 11 spawning sites (1-11) in Lake Femund. S.D. = standard deviation, C.V. = coefficient of variation (mean/S.D.). Data on sites are given in table 2 and figure 1.

\begin{tabular}{lccccccccccc}
\hline & 1 & 2 & 3 & 4 & 5 & 6 & 7 & 8 & 9 & 10 & 11 \\
\hline Gill rakers & & & & & & & & & & & \\
$\quad$ Mean & 28.2 & 28.3 & 28.6 & 28.7 & 29.7 & 31.5 & 44.7 & 36.0 & 35.4 & 37.6 & 40.6 \\
SD & 2.1 & 1.9 & 1.8 & 1.5 & 2.9 & 3.9 & 2.4 & 2.2 & 1.6 & 3.3 & 3.2 \\
Range & $25-33$ & $25-34$ & $25-33$ & $25-32$ & $25-38$ & $25-42$ & $40-51$ & $30-44$ & $33-39$ & $32-45$ & $33-47$ \\
C.V. & 0.07 & 0.07 & 0.06 & 0.05 & 0.10 & 0.12 & 0.05 & 0.06 & 0.05 & 0.09 & 0.08 \\
Body length (cm) & & & & & & & & & & & \\
Mean & 30.0 & 30.3 & 30.1 & 29.5 & 33.1 & 36.2 & 37.9 & 34.4 & 34.6 & 35.9 & 37.1 \\
S.D. & 1.5 & 1.2 & 1.3 & 1.1 & 3.2 & 4.9 & 2.7 & 1.7 & 2.1 & 3.0 & 2.4 \\
Range & $27.8-33.5$ & $27.0-33.5$ & $26.4-32.5$ & $27.2-32.8$ & $27.5-39.3$ & $28.2-46.2$ & $32.3-43.7$ & $30.9-38.7$ & $30.5-41.5$ & $32.0-44.0$ & $30.8-41.5$ \\
C.V. & 0.05 & 0.04 & 0.04 & 0.04 & 0.10 & 0.14 & 0.07 & 0.05 & 0.06 & 0.08 & 0.06 \\
Age (yrs) & & & & & & & & & & & \\
Mean & 11.8 & 11.8 & 13.4 & 9.4 & 11.2 & 16.1 & 7.6 & 9.4 & 10.0 & 9.1 & 8.4 \\
S.D. & 3.3 & 3.3 & 2.6 & 2.8 & 2.8 & 5.7 & 4.2 & 2.6 & 3.1 & 1.8 & 1.7 \\
Range & $7-17$ & $6-20$ & $7-21$ & $7-18$ & $7-17$ & $7-30$ & $3-25$ & $6-17$ & $7-22$ & $7-16$ & $6-15$ \\
C.V. & 0.28 & 0.28 & 0.19 & 0.30 & 0.25 & 0.35 & 0.55 & 0.28 & 0.31 & 0.20 & 0.20 \\
No. fish & 23 & 60 & 49 & 56 & 38 & 35 & 78 & 90 & 50 & 40 & 77 \\
\hline
\end{tabular}

examined. The shortest water-surface distances between sampling sites denote geographic distances. In addition, a possible correlation between morphological differentiation and genetic distance was tested. The significance of matrix relationships was assessed with the simple Mantel test by using NTSYSpc software (Rohlf 1998). The confidence of the t-statistic was evaluated with 1,000 random permutations. Prior to testing, the matrices were normalized.

\section{RESULTS}

\subsection{Phenotypic variation}

The studied samples of spawning whitefish in Lake Femund differed in their spawning habitat (deep water, shallow water, river), time of spawning (from October to November), number of gillrakers (mean from 28.2 to 44.7 ), body length (mean from 29.5 to $37.9 \mathrm{~cm}$ ), and age (mean from 7.6 to $16.1 \mathrm{yrs}$ ) (Tabs 2 and 3 ). The deepwater spawners (ecotype I, sites 1 to 4) spawned in November and had mean gillraker counts between 28 and 29, with a relatively small variation in numbers (C.V. $=0.05-0.07)$. Mean body lengths in the samples from these populations were between 29.5 and 30.3 $\mathrm{cm}$. Of the shallow water spawning populations (ecotype II), two (sites 5 and 6) spawned in November and had low gillraker numbers (29.7 and 31.5). The third population representing ecotype II (site 7) spawned in October and had higher gillraker numbers (44.7). Fish representing ecotype II (mean length 33.1 to $37.9 \mathrm{~cm}$ ) were larger than fish of ecotype I. The four populations spawning in or close to rivers (ecotype III, sites 8 to 11) spawned in October and had similar body length to the shallow water spawners (34.4 to $37.1 \mathrm{~cm})$. However, the gillraker numbers varied (35.4 to 40.6 ), but were higher than in the deepwater and two of the shallow water spawning populations (sites 1 to 6 ).

Significance tests for the equality of spawning locality group means indicate that the largest differences between spawning populations are found in gillraker numbers, followed by body length, and age (univariate $F$-ratio test: $F=297.8,106.79$, and 23.68 , respectively; 10 and 504 d.f., $P<0.0001$ for all groups). Among spawning groups, the within-group variability of gillraker number is small compared to the total variability (Wilks' $\lambda=0.147$ ). The within-group variability of body length and age are larger (Wilks' $\lambda=0.321$ and 0.680 , respectively). Hence, gillraker number seems to be the best single variable of the three to distinguish between the spawning populations.

In a discriminant analysis predicting sample membership based on gillraker number, body length and age, $51 \%$ of the whitefish were correctly classified (Tab. 4). This analysis indicates that spawning sites 1 to 4 group together. This corresponds to ecotype I. If the four populations are pooled, $97 \%$ of the fish were correctly classified. However, classification to each of the four samples varied between 21 and $71 \%$. Most of the fish from spawning populations 6 and 7 were also correctly classified (72 and $80 \%$, respectively). However, only $15 \%$ of fish from spawning site 10 were correctly classified. Spawning site 9 was situated in the river delta of River Tufsinga, which is the spawning site of population 8. Accordingly, the discriminant analysis shows that these two populations were closely linked, as 94\% were correctly classified if the two populations were pooled.

The hierarchical cluster analysis based on gillraker number, age and length, grouped the populations into two major groups (Fig. 3a), populations 1-6 and populations 7-11. Within these major groupings, fish from the four deepwater sites (1-4; Fig. 1) and one of the shallow water sites (5) grouped close together, whereas population 6 , the other shallow water site, clearly stands apart. Fish from the three spawning sites in, or closely associated with, inlet rivers (sites 8-10) also grouped together. 
Tab. 4. Discriminant analysis classification of individual whitefish by the variables gillraker number, age and length.

\begin{tabular}{cccccccccccccc}
\hline Actual group & \multirow{2}{*}{ No. of cases } & \multicolumn{10}{c}{ Predicted group membership (\%) } \\
\cline { 2 - 12 } & & 1 & 2 & 3 & 4 & 5 & 6 & 7 & 8 & 9 & 10 & 11 \\
\hline 1 & 11 & $\mathbf{4 6}$ & 9 & 27 & 18 & 0 & 0 & 0 & 0 & 0 & 0 & 0 \\
2 & 60 & 17 & $\mathbf{2 1}$ & 23 & 32 & 3 & 0 & 0 & 0 & 3 & 0 & 0 \\
3 & 49 & 20 & 14 & $\mathbf{5 3}$ & 12 & 0 & 0 & 0 & 0 & 0 & 0 & 0 \\
4 & 56 & 7 & 2 & 14 & $\mathbf{7 1}$ & 5 & 0 & 0 & 0 & 0 & 0 & 0 \\
5 & 38 & 3 & 11 & 8 & 16 & $\mathbf{4 5}$ & 11 & 0 & 3 & 3 & 3 & 0 \\
6 & 18 & 0 & 6 & 0 & 0 & 11 & $\mathbf{7 2}$ & 0 & 0 & 0 & 0 & 11 \\
7 & 78 & 0 & 0 & 0 & 0 & 0 & 1 & $\mathbf{8 0}$ & 0 & 0 & 0 & 19 \\
8 & 69 & 0 & 0 & 0 & 0 & 6 & 4 & 1 & $\mathbf{5 4}$ & 22 & 12 & 1 \\
9 & 30 & 0 & 0 & 0 & 0 & 0 & 7 & 0 & 37 & $\mathbf{5 7}$ & 0 & 0 \\
10 & 40 & 0 & 0 & 0 & 0 & 3 & 0 & 10 & 38 & 15 & $\mathbf{1 5}$ & 20 \\
11 & 66 & 0 & 0 & 0 & 0 & 0 & 0 & 24 & 15 & 5 & 14 & $\mathbf{4 2}$ \\
\hline
\end{tabular}
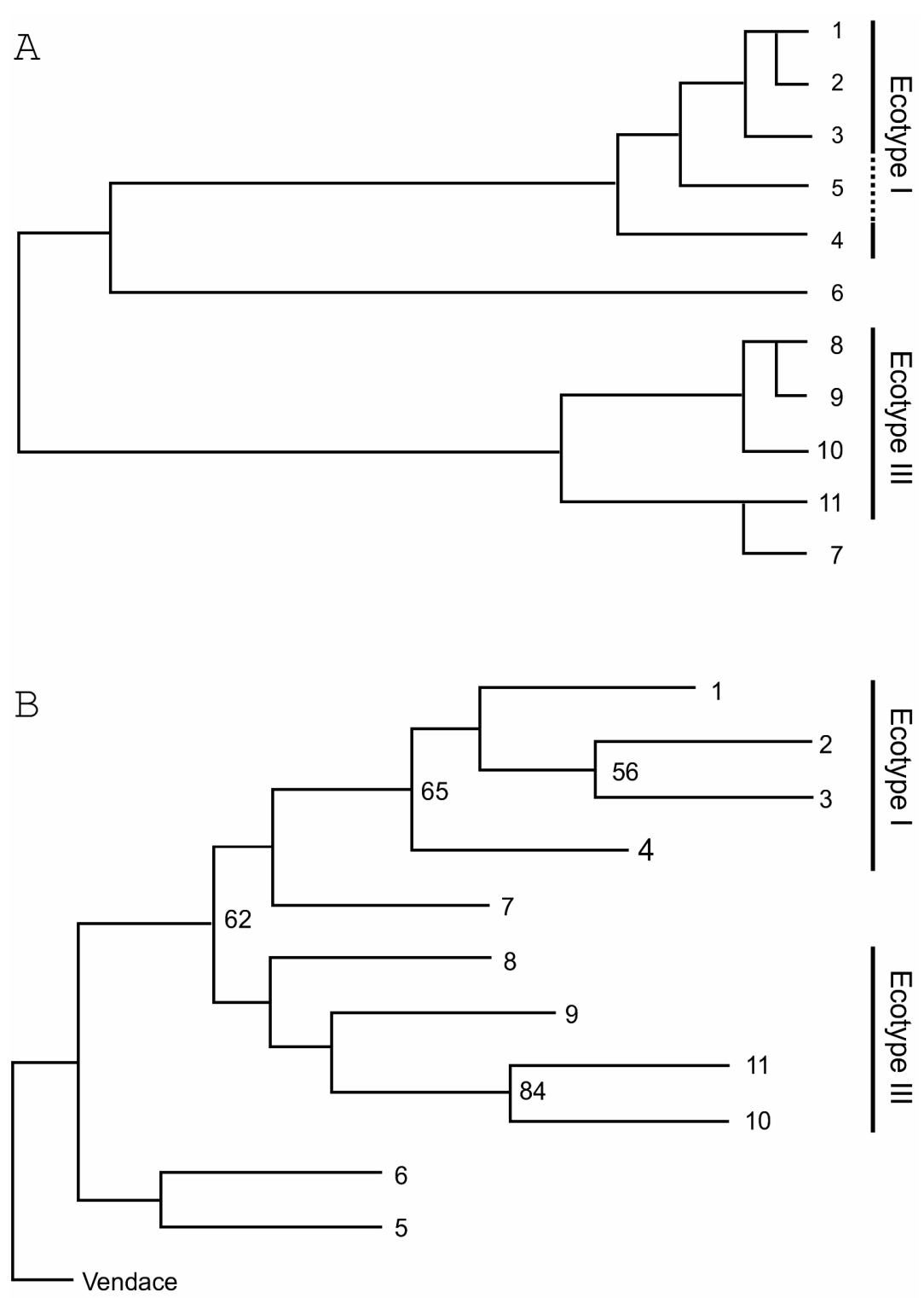

Fig. 3. A. Average linkage between 11 spawning sites (Pop. no.) in Lake Femund as shown by hierarchical cluster analysis of the variables: mean gillraker number, mean body length and mean age of mature fish. B. Neighbour joining consensus tree showing genetic relationships of 11 whitefish samples from Lake Femund. The dendrogram is based on Cavalli-Sforza \& Edwards (1967) arc distances calculated from allele frequencies at nine loci. Bootstrap proportions are given for statistically supported groupings ( $>50 \%)$. Two of the three a priori defined ecotypes (cf. table 2) are shown with vertical bars. Sites 5-7 represent ecotype II. 
Tab. 5. Estimated allele frequencies for 9 polymorphic loci, and percentage of polymorphic loci and heterozygosity based on 38 loci in 11 collections of whitefish from Lake Femund, Norway. Sample sizes are in parenthesis. Site names are given in table 2 .

\begin{tabular}{|c|c|c|c|c|c|c|c|c|c|c|c|c|}
\hline \multirow[b]{2}{*}{ Locus } & \multirow[b]{2}{*}{ allele } & \multicolumn{11}{|c|}{ Site number / (sample size) } \\
\hline & & $\begin{array}{c}1 \\
(41)\end{array}$ & $\begin{array}{c}2 \\
(60)\end{array}$ & $\begin{array}{c}3 \\
(49)\end{array}$ & $\begin{array}{c}4 \\
(56)\end{array}$ & $\begin{array}{c}5 \\
(38)\end{array}$ & $\begin{array}{c}6 \\
(35)\end{array}$ & $\begin{array}{c}7 \\
(78)\end{array}$ & $\begin{array}{c}8 \\
(90)\end{array}$ & $\begin{array}{c}9 \\
(60)\end{array}$ & $\begin{array}{c}10 \\
(40)\end{array}$ & $\begin{array}{c}11 \\
(77)\end{array}$ \\
\hline \multicolumn{13}{|c|}{$m A A T^{*}$} \\
\hline & $*-100$ & 0.939 & 0.908 & 0.918 & 0.934 & 0.974 & 1.000 & 0.974 & 0.994 & 1.000 & 0.987 & 0.994 \\
\hline & $*-120$ & 0.061 & 0.092 & 0.082 & 0.066 & 0.026 & 0.000 & 0.026 & 0.006 & 0.000 & 0.013 & 0.006 \\
\hline \multicolumn{13}{|c|}{$s A A T-2^{*}$} \\
\hline & $* 100$ & 0.963 & 1.000 & 1.000 & 1.000 & 0.961 & 0.943 & 1.000 & 1.000 & 1.000 & 1.000 & 1.000 \\
\hline & $* 110$ & 0.037 & 0.000 & 0.000 & 0.000 & 0.039 & 0.057 & 0.000 & 0.000 & 0.000 & 0.000 & 0.000 \\
\hline \multicolumn{13}{|c|}{$G 3 P D H-2 *$} \\
\hline & $* 100$ & 0.805 & 0.692 & 0.755 & 0.670 & 0.697 & 0.857 & 0.628 & 0.586 & 0.708 & 0.450 & 0.463 \\
\hline & $* 50$ & 0.195 & 0.308 & 0.245 & 0.330 & 0.303 & 0.143 & 0.372 & 0.414 & 0.292 & 0.550 & 0.537 \\
\hline \multicolumn{13}{|c|}{ G3PDH-3* } \\
\hline & $* 100$ & 1.000 & 0.967 & 0.939 & 0.955 & 0.882 & 0.929 & 0.531 & 0.878 & 0.890 & 0.962 & 0.909 \\
\hline & $* 70$ & 0.000 & 0.000 & 0.000 & 0.027 & 0.053 & 0.057 & 0.347 & 0.094 & 0.093 & 0.013 & 0.020 \\
\hline & *65 & 0.000 & 0.033 & 0.061 & 0.018 & 0.066 & 0.014 & 0.122 & 0.028 & 0.017 & 0.025 & 0.071 \\
\hline \multicolumn{13}{|c|}{$G P I-A 2^{*}$} \\
\hline & $* 100$ & 0.268 & 0.208 & 0.255 & 0.259 & 0.368 & 0.243 & 0.256 & 0.278 & 0.225 & 0.325 & 0.454 \\
\hline & $* 105$ & 0.732 & 0.792 & 0.745 & 0.741 & 0.632 & 0.757 & 0.744 & 0.722 & 0.775 & 0.675 & 0.546 \\
\hline \multicolumn{13}{|c|}{$L D H-A 1^{*}$} \\
\hline & $* 100$ & 0.963 & 0.958 & 0.949 & 0.946 & 1.000 & 0.986 & 0.974 & 0.944 & 0.883 & 0.913 & 0.922 \\
\hline & $* 65$ & 0.037 & 0.042 & 0.051 & 0.054 & 0.000 & 0.014 & 0.026 & 0.056 & 0.117 & 0.087 & 0.078 \\
\hline \multicolumn{13}{|c|}{$s M D H-A 2 *$} \\
\hline & $* 100$ & 0.744 & 0.658 & 0.755 & 0.768 & 0.961 & 0.957 & 0.833 & 0.889 & 0.867 & 0.962 & 0.955 \\
\hline & $* 50$ & 0.256 & 0.342 & 0.245 & 0.232 & 0.039 & 0.043 & 0.167 & 0.111 & 0.133 & 0.038 & 0.045 \\
\hline \multicolumn{13}{|c|}{$s M D H-B 1^{*}$} \\
\hline & $* 120$ & 0.683 & 0.600 & 0.423 & 0.728 & 0.375 & 0.343 & 0.404 & 0.378 & 0.633 & 0.594 & 0.617 \\
\hline & $* 100$ & 0.317 & 0.400 & 0.577 & 0.272 & 0.625 & 0.643 & 0.590 & 0.622 & 0.367 & 0.406 & 0.357 \\
\hline & *90 & 0.000 & 0.000 & 0.000 & 0.000 & 0.000 & 0.014 & 0.006 & 0.000 & 0.000 & 0.000 & 0.026 \\
\hline \multicolumn{13}{|c|}{$s M D H-B 2 *$} \\
\hline & $* 120$ & 0.683 & 0.783 & 0.883 & 0.728 & 0.849 & 0.800 & 0.872 & 0.689 & 0.617 & 0.669 & 0.617 \\
\hline & $* 100$ & 0.317 & 0.217 & 0.117 & 0.272 & 0.151 & 0.200 & 0.128 & 0.311 & 0.375 & 0.306 & 0.357 \\
\hline & $* 90$ & 0.000 & 0.000 & 0.000 & 0.000 & 0.000 & 0.000 & 0.000 & 0.000 & 0.008 & 0.025 & 0.026 \\
\hline $\mathrm{P}_{0.95 \text { crit }}$ & & 15.8 & 15.8 & 21.1 & 18.4 & 13.2 & 15.8 & 15.8 & 18.4 & 18.4 & 13.2 & 15.8 \\
\hline $\mathrm{H}_{\exp }$ & & 0.058 & 0.062 & 0.057 & 0.060 & 0.054 & 0.046 & 0.066 & 0.061 & 0.062 & 0.058 & 0.063 \\
\hline
\end{tabular}

The shallow water spawners from Kvernvika (site 7) were quite close to the spawners from the lake outlet at Gløtfossen (site 11). Adding spawning depth and spawning month to some extent changed the clustering, although populations 1-4 and 8-10 still clustered together in two separate groups. Thus, the cluster analysis based on phenotypic characters does not correspond well with the a priori ecotype grouping.

\subsection{Genetic variation}

Nine of the 38 loci were polymorphic at the 0.95 level in one or more of the samples. Allele frequencies at these loci are given in table 5. Furthermore, single heterozygotes were observed for the following alleles: $C K-A 1,2 * 85$ (Storvika, site 3 ), sIDHP-4*118 (Vestfjorden, site 4), and $P G M-2 *-155$ (Hullet, site 2; Tjønnan, site 9). All genotypic proportions conformed to Hardy-Weinberg expectation when the probability levels were adjusted according to 83 simultaneous tests carried out (Lessios 1992).

The level of genetic variation among samples was quite similar (Tab. 5). The average expected het- erozygosities varied from 0.046 to 0.066 and the percentage of polymorphic loci ranged from $13.2 \%$ to $21.1 \%$. The lowest heterozygosity value was recorded in Hallsteinvika (site 6), where the spawning population is considered to be small (Næsje et al. 1992).

Although the amount of genetic variation is comparable, there are substantial allele frequency differences at individual loci among samples (Tab. 5). The frequency of the 100 allele at $G 3 P D H-3^{*}$ is only 0.531 among the high rakered Kvernvika (site 7) fish but is 0.878 or higher in all other samples, and it is fixed in Joneset (site 1) fish. At $s M D H-A 2 *$ loci, the frequency of the 50 allele was higher $(0.232-0.342)$ in the four deepwater sites (1-4) representing ecotype I than in the other samples (sites 5-11;0.038-0.167). Ecotype I fish also differed from the others by having higher frequencies of the variant allele at $m A A T^{*}$. This heterogeneity among samples was confirmed by the preliminary contingency $\chi^{2}$ test which yielded highly significant $(P<<0.001)$ differences at all polymorphic loci with the exception of $L D H-A 1 *$ where the populations differed at $P=0.012$. 
Population differentiation was evidenced also by $\mathrm{F}_{\mathrm{ST}}$ values ranging from 0.032 to 0.155 with a mean of 0.0631 . The highest $\mathrm{F}_{\mathrm{ST}}$ value was at $G 3 P D H-3 *$ where Kvernvika (site 7) fish had very different allele frequencies. In a hierarchical analysis the three ecotypes accounted for $40 \%$ of the overall genetic differentiation, with $S M D H-A 2 *$ showing the highest level of differentiation with $\mathrm{F}_{\mathrm{ST}}=0.056$.

Genetic affinities of Lake Femund whitefish are presented in a consensus tree (Fig. 3b). Deepwater spawners from north and south basins (sites 1-4) cluster together with $65 \%$ support. Moreover, the running water spawners from the southern end of the lake (sites 10-11) also pair up with $84 \%$ support. The remaining groupings have only low statistical support. The high rakered Kvernvika whitefish (site 7) is placed with low rakered deepwater spawners, two river-connected samples from north basin (sites 8 and 9) cluster with two river samples from the south basin (sites 10 and 11), and two shallow-water spawners (sites 5 and 6) from the opposite ends of the south basin group together. The general picture is that the grouping is based on the spawning depth and/or trophic morphology rather than on the geographical proximity. All deepwater fish from both basins group together whereas adjacent samples differing by their behaviour or morphology (like 5 and 11 or 6 and 7) cluster far apart. The four populations associated with river systems also group together although two of them with low support. This parallels with the results of contingency $\chi^{2}$ test, which indicated highly significant overall differences among these four sites. Among the four deepwater samples, there was no overall difference but the southernmost Joneset site (1) differed from three others at two AAT loci. The clustering based on genetic data fits relatively well with the a priori ecotype groups I and III, whereas ecotype II is not recognized in the consensus tree.

Genetic distances were not correlated with geographic distance (Mantel's $r=0.142, P=0.19$ ), i.e. geographical proximity does not predict genetic similarity of spawning populations. On the contrary, genetic distances were highly correlated with morphological distances (Mantel's $r=0.627, P=0.002$ ) and with gillraker numbers (Mantel's $r=0.591, P=0.003$ ).

\section{DISCUSSION}

The various spawning populations of whitefish in Lake Femund are genetically different, and there is a close association between differences in gillraker numbers and genetic differences. Populations with similar gillraker counts also tend to be genetically similar. Differentiation among spawning populations is very clear in gillraker numbers, but less so in age and length at sexual maturity. This is in accordance with previous studies of whitefish, where number of gillrakers has been shown to be a stable character with a large element of heritability (Svärdson 1979; Lindsey 1981). The body length of mature fish, on the other hand, is to a large extent determined by food availability and physical environment (e.g., water temperature) during ontogeny. Usually, growth rates are very low in adult whitefish. In Femund, high juvenile growth rates should be expected in fish living in shallow areas, whereas fish living in deep waters should experience lower growth rates and late sexual maturation (Sandlund et al. 1995; Saksgård et al. 2002). Whitefish is a long-lived iteroparous species. Consequently, mean age in adult fish depends on age at sexual maturity as well as fishing pressure and other mortality factors in adult fish.

The concordance between the two independent data sets is fairly good indicating at least some genetic basis for the phenotypic variability. The significant correlation between genetic distance and morphological distance was assessed by the Mantel test of matrix association. The cluster analyses based on two separate data sets also produced parallel results even though there is some discordance in the placement of some populations (Fig. 3). One of the two main groupings based on morphology/life history variables includes sites 1-6. In the consensus tree based on genetic data these sites form two separate groupings, one including ecotype I fish (sites 1-4) with high bootstrap support, whereas the other grouping is formed by sites 5-6 with low statistical support. The other main cluster based on morphology includes sites 7-11, all with high gillraker numbers (Tab. 3). In the consensus tree based on genetic data the placing of high rakered Kvernvika whitefish (site 7) is different. It groups with deepwater whitefish but the statistical support is low. The remaining four populations associated with running water (sites 8-11) form a separate grouping although two of these sites have low bootstrap values.

There is no geographic pattern in the genetic variation. This would be expected if genetic drift and migration are the major factors controlling population differentiation. While the spawning sites of the whitefish populations are geographically separated, there is considerable overlap in spawning time. Therefore migrants could potentially spawn in localities other than their home site. There are no exact data on the degree of straying between spawning sites in Lake Femund, but the pattern of population differentiation indicates that any homogenizing effect of gene flow is outweighed by the diversifying effects of other evolutionary processes.

The investigated spawning populations are separate entities, with significant differences in genetic structure. The differences in gillraker counts between populations are closely associated with genetic differences. Thus, the morphological differences are not due to phenotypic plasticity as is commonly seen in other fish species (Skúlason \& Smith 1995). In Arctic charr, 
for instance, the polymorphism observed within one lake may be due to phenotypic plasticity within single spawning populations, as well as reproductively separated populations that differ in morphology and genetics (Hindar et al. 1986; Sandlund et al. 1992; Hindar \& Jonsson 1993). In Arctic charr, sympatric but separated spawning populations appear to have developed sympatrically within lakes (Hindar et al. 1986).

Several recent investigations have demonstrated a similar situation of sympatric forms in both European (C. lavaretus) and North American whitefish (C. clupeaformis) (Douglas et al. 1999; Lu \& Bernatchez 1999). In other cases, the co-occurring whitefish forms are of allopatric origin (Bernatchez et al. 1996; Pigeon et al. 1997).

There are three alternative scenarios for the emergence of the state of "polymorphism" observed in Femund whitefish. One is that a monomorphic immigrant population radiated into various forms due to a phenotypic response to different available niches. In this case, no genetic difference between the morphs should be expected (Douglas et al. 1999).

The second scenario implies that a monomorphic immigrant population occupied the various available spawning sites, and that the resulting spawning populations eventually became morphologically different and reproductively segregated by the so-called "divergence-with-gene flow" model (Rice \& Hostert 1993; Foster et al. 1998). The well documented homing tendency among salmonids would be an important factor in maintaining this structure (Brannon \& Jonsson 1989). Differential selection pressures in different spawning and hatching environments would cause the divergence of the populations (Lu \& Bernatchez 1999; Douglas et al. 1999). This study also presents some indirect evidence of such selection. In a plot of $\mathrm{F}_{\mathrm{ST}} v \mathrm{~s}$ heterozygosity in nine polymorphic loci (data not shown) $s M D H-A 2 *$ had clearly outlying value. It is likely that geographically varying selection has been acting at this or at a closely linked locus (Beaumont \& Nichols 1996). Genetic drift and founder effects might also play a part in the development of differences. Had founder effect played any significant role, however, we would have expected the heterozygosity within populations to be significantly lower than what is observed in whitefish elsewhere. This is not the case (Vuorinen et al. 1986). There are many documented instances among salmonids as well as other fish taxa where evidence indicates sympatric divergence in important characters, e.g. morphology, life history, trophic ecology, and spawning time and habitat (e.g. Hindar et al. 1986; Sandlund et al. 1992; Klemetsen et al. 1997; Foster et al. 1998; Magurran 1998; Douglas et al. 1999; Lu \& Bernatchez 1999; Danley \& Kocher 2001).

The third scenario is that several whitefish forms with different genetics, morphology, and ecology entered the lake during and after deglaciation, occupying different spawning localities and maintaining their differences (cf. Bernatchez et al. 1996). The form would have developed prior to immigration in geographical isolation with no gene flow, according to the traditional geographical or allopatric divergence model (Mayr 1963). The relatively small genetic differentiation between the Femund whitefish populations may indicate a short period since separation (cf. Vuorinen et al. 1986; Bodaly et al. 1991; Bernatchez \& Wilson 1998). Geographical isolation between coregonid populations may lead to very swift genetic differentiation. In vendace (C. albula, a closely related species), Vuorinen et al. (1991) have shown that less than 100 yrs of geographical isolation may bring about large genetic differences without loss of heterozygosity. In grayling ( $T$. thymallus), significant differences in genetic and phenotypic characters, caused by natural selection, have been demonstrated in populations that have been geographically isolated for less than 125 years (Koskinen et al. 2002). Thus, it would be expected that geographical isolation of the whitefish forms during glaciation (approximately 10,000 years before present) would have caused larger genetic differences than observed here.

An intermediate model may also be envisaged, where two or more forms immigrated and subsequently radiated into several distinct spawning populations. A process involving introgression between the immigrating forms, as proposed by Svärdson (1979), is also theoretically possible, and has been documented in other species pairs of fish (cf. Epifanio \& Philipp 2001). A larger geographical survey is required to evaluate this hypothesis.

\section{CONCLUSIONS}

In conclusion, the data presented here do not provide an unequivocal answer to the question of sympatric or allopatric emergence of morphs. It is, however, demonstrated that a number of morphologically, ecologically and genetically different spawning populations of whitefish do coexist in Lake Femund. Moreover, the genetic differences are associated with differences in gillraker counts, and to a small extent also with spawning habitat, but not with geographic distance between spawning sites. Management of the whitefish stocks is presently based on gillraker number (Sandlund \& Næsje 1989; Næsje et al. 1992; Sandlund et al. 2002). With the documented association between differences in gillraker counts and genetic differentiation, this appears to be a sensible practice. However, special care should be taken to protect some of the less numerous and genetically and ecologically different populations, such as the one spawning in Kvernvika (site 7) and in Sorkelva (site 10).

\section{ACKNOWLEDGMENTS}

We thank the staff of Femund Fiskerlag for their assistance in obtaining fish from spawning grounds, 
and their unfailing support of our research work in the lake. This work has been financially supported by the Directorate for Nature Management (DN) and Norwegian Institute for Nature Research (NINA). We are also indebted to Matti Koistinen for assistance in the laboratory. This work was supported by grant 8001114 from the Finnish Academy to J.A.V.

\section{REFERENCES}

Beaumont, M.A. \& R.A. Nichols. 1996. Evaluating loci for use in the genetic analysis of population structure. Proceedings of the Royal Society of London Ser. B, 263: 1619-1626.

Bernatchez, L. 2004. Ecological theory of adaptive radiation. An empirical assessment from coregonine fishes (Salmoniformes). In: A.P. Hendry \& S.C. Stearns (Eds), Evolution Illuminated. Salmon and their Relatives. Oxford University Press, Oxford: pp. 175-207.

Bernatchez, L. \& C.C. Wilson. 1998. Comparative phylogeography of Nearctic and Palearctic fishes. Molecular Ecology, 7: 431-452.

Bernatchez, L., A. Chouinard \& G. Lu. 1999. Integrating molecular genetics and ecology in studies of adaptive radiation: whitefish, Coregonus sp.; as a case study. Biological Journal of the Linnean Society, 68: 173-194.

Bernatchez, L., J.A. Vuorinen, R.A. Bodaly \& J.J. Dodson. 1996. Genetic evidence for reproductive isolation and multiple origins of sympatric trophic ecotypes of whitefish (Coregonus). Evolution, 50: 624-635.

Birt, T.P., J.M. Green \& W.S. Davidson. 1991. Mitochondrial DNA variation reveals genetically distinct sympatric populations of anadromous and nonanadromous Atlantic salmon, Salmo salar. Can. J. Fish. Aquat. Sci., 48: 577-582.

Black, W.C., IV. 1997. BIOSYS-2. A computer program for the analysis of allelic variation in genetics. Colorado State University, Ft. Collins, Colorado.

Bodaly, R.A., J.W. Clayton, C.C. Lindsey \& J. Vuorinen. 1992. Evolution of lake whitefish (Coregonus clupeaformis) in North America during the Pleistocene: genetic differentiation between sympatric populations. Can. J. Fish. Aquat. Sci., 49: 769-779.

Bodaly, R.A., J. Vuorinen, R.D. Ward, M. Luczynski \& J.D. Reist. 1991. Genetic comparisons of New and Old World coregonid fishes. J. Fish Biol., 38: 37-51.

Brannon, E. \& B. Jonsson (Eds). 1989. Proceedings of the Salmonid Migration and Distribution Symposium. School of Fisheries, Univ. of Washington, Seattle, USA and Norwegian Institute for Nature Research, Trondheim, Norway.

Cavalli Sforza, L.L. \& A.W.F. Edwards. 1967. Phylogenetic analysis: Models and estimation procedures. Evolution, 21: 550570.

Claytor, R.R. \& E. Verspoor. 1991. Discordant phenotypic variation in sympatric resident and anadromous Atlantic salmon (Salmo salar) populations. Can. J. Zool., 69: 2846-2852.

Danley, P.D. \& T.D. Kocher. 2001. Speciation in rapidly diverging systems: Lessons from Lake Malawi. Molecular Ecology, 10: 1075-1086

Douglas, M.R., P.C. Brunner \& L. Bernatchez. 1999. Do assemblages of Coregonus (Teleostei: Salmoniformes) in the Central Alpine region of Europe represent species flocks? Molecular Ecology, 8: 589-603.

Epifanio, J. \& D. Philipp. 2001. Simulating the extinction of parental lineages from introgressive hybridization: the effects of fitness, initial proportions of parental taxa, and mate choice. Rev. Fish Biol. Fish., 10: 339-354.
Felsenstein, J. 1993. PHYLIP (Phylogeny Inference Package) version $3.5 \mathrm{c}$. Distributed by the author. Department of Genetics, University of Washington, Seattle. http://evolution.genetics.washington.edu/phylip.html.

Ferguson, A. \& J.B. Taggart. 1991. Genetic differentiation among the sympatric brown trout (Salmo trutta) populations of Lough Melvin, Ireland. Biological Journal of the Linnean Society, 43: 221-237.

Foster, S.A., R.J. Scott \& W.A. Cresko. 1998. Nested biological variation and speciation. Phil. Trans. Royal Soc., London. Ser. B Biological Sciences, 353: 207-218.

Hansen, M.M., K.-L.D. Mensberg \& S. Berg. 1999. Postglacial recolonization patterns and genetic relationships among whitefish (Coregonus sp.) populations in Denmark, inferred from mitochondrial DNA and microsatellite markers. Molecular Ecology, 8: 239-252.

Hindar, K. 1994. Alternative life histories and genetic conservation. In: V. Loeschke et al. (Eds), Conservation Genetics. Birkhäuser Verlag, Basel: 323-336.

Hindar, K. \& B. Jonsson. 1993. Ecological polymorphism in Arctic charr. Biological Journal of the Linnean Society, 48: 63-74.

Hindar, K., N. Ryman \& G. Ståhl. 1986. Genetic differentiation among local populations and morphotypes of Arctic charr, Salvelinus alpinus. Biological Journal of the Linnean Society, 27: 269-285.

Kirkpatrick, M. \& R.K. Selander. 1979. Genetics of speciation in lake whitefishes in the Allegash Basin. Evolution, 33: 478-485.

Klemetsen, A., P.-A. Amundsen, R. Knudsen \& B. Hermansen. 1997. A profundal, winter-spawning morph of Arctic charr Salvelinus alpinus (L.) in Lake Fjellfrøsvatn, Northern Norway. Nordic Journal of Freshwater Research, 73: 13-23.

Koskinen, M.T., T.O. Haugen \& C.R. Primmer. 2002. Contemporary fisherian life-history evolution in small salmonid populations. Nature, 419: 826-830.

Lessios, H.A. 1992. Testing electrophoretic data for agreement with Hardy-Weinberg expectations. Mar. Biol., 112: 517-523.

Lindsey, C.C. 1981. Stocks are chameleons: plasticity in gillrakers of coregonid fishes. Can. J. Fish. Aquat. Sci., 38: 1497-1506.

Løvik, J.E. \& G. Kjellberg. 1982. Glåma i Hedmark. Delrapport om dyreplankton. Undersøkelser i tidsrommet 1978-80. Norwegian Institute of Water Research, Report No. 78045-III: 1-58. (In Norwegian).

Lu, G. \& L. Bernatchez. 1999. Correlated trophic specialization and genetic divergence in sympatric lake whitefish ecotypes (Coregonus clupeaformis): support for the ecological speciation hypothesis. Evolution, 53: $1491-1505$.

Magnusson, K.P. \& M.M. Ferguson. 1987. Genetic analysis of four sympatric morphs of arctic charr, Salvelinus alpinus, from Thingvallavatn, Iceland. Environmental Biology of Fishes, 20: 67-73.

Magurran, A.E. 1998. Population differentiation without speciation. Phil. Trans. Royal Soc., London. Ser. B Biological Sciences, 353: 275-286.

Mayr, E. (1963). Animal species and evolution. Belknap Press, Cambridge, Mass.

Næsje, T.F., O.T. Sandlund \& R. Saksgård. 1992. Siken i Femund: effekter og anbefalinger etter ti års næringsfiske. NINA-Oppdragsmelding, 145: 1-24. (In Norwegian, English summary).

Næsje, T.F., O.T. Sandlund \& R. Saksgård. 1998. Selective predation of piscivorous brown trout (Salmo trutta L.) on polymorphic whitefish (Coregonus lavaretus L.). Arch. Hydrobiol. Special Issues Advances in Limnology, 50: 283-294. 
Nei, M. 1978. Estimation of average heterozygosity and genetic distance from a small number of individuals. Genetics, 89: 583-590.

Pigeon, D., A. Chouinard \& L. Bernatchez. 1997. Multiple modes of speciation involved in the parallel evolution of sympatric morphotypes of lake whitefish (Coregonus clupeaformis, Salmonidae). Evolution, 51: 196-205.

Rice, W.R. \& E.E. Hostert. 1993. Laboratory experiments on speciation: what have we learned in 40 years? Evolution, 47: 1637-1653

Robinson, B.W. \& D.S. Wilson. 1994. Character release and displacement in fishes: a neglected literature. Am. Nat., 144: 596-627.

Rohlf, F.J. 1998. NTSYS-pc, numerical taxonomy and multivariate analysis system, ver $2.02 k$. Distributed by Exeter Software. Setauket, New York.

Ryman, N., F.W. Allendorf \& G. Ståhl. 1979. Reproductive isolation with little genetic divergence in sympatric populations of brown trout (Salmo trutta). Genetics, 92: 247-262.

Saint-Laurent, R., M. Legault \& L. Bernatchez. 2003. Divergent selection maintains adaptive differentiation despite high gene flow between sympatric rainbow smelt ecotypes (Osmerus mordax Mitchill). Molecular Ecology, 12: 315-330.

Saksgård, R., T.F. Næsje, O.T. Sandlund \& O. Ugedal. 2002. The effect of fish predators on European whitefish (Coregonus lavaretus L.) habitat use in Lake Femund, a deep Norwegian lake. Arch. Hydrobiol. Special Issues Advances in Limnology, 57: 537-552.

Sandlund, O.T. 1986. The annual catch of whitefish (Coregonus lavaretus) in the River Tufsinga, Eastern Norway. Norsk Skogbruksmuseum, Arbok, 11: 284-296. (In Norwegian, English summary).

Sandlund, O.T. \& T.F. Næsje. 1986. Sikbestanden $i$ Femund. Undersøkelser 1982-84. Report from the Fish Research Division, Directorate of Nature Management, No. 2: 151. (In Norwegian, English summary).

Sandlund, O.T. \& T.F. Næsje. 1989. Impact of a pelagic gillnet fishery on the polymorphic whitefish (Coregonus lavaretus L. s.1.) population in Lake Femund, Norway. Fish. Res., 7: 85-97.

Sandlund, O. T. \& T. F. Næsje. 1996. A successful smallscale fishery cooperative in a high-cost country - a case study. In: R.A. Neal (Ed.), Proceedings of the World Fisheries Congress, Theme 4 International development. Oxford \& IBH Publishing Co., New Dehli: 49-57.

Sandlund, O.T., T.F. Næsje \& R. Saksgård. 1995. Ecological diversity in whitefish Coregonus lavaretus: ontogenetic niche shifts and polymorphism. Arch. Hydrobiol. Special Issues Advances in Limnology, 46: 49-59.

Sandlund, O.T., T.F. Næsje, R. Saksgård \& K. Østbye. 2002. Gillraker development in juvenile polymorphic European whitefish (Coregonus lavaretus L.) in Lake Femund, Norway. Arch. Hydrobiol. Special Issues Advances in Limnology, 57: 553-562.

Sandlund, O.T., E. Berge, B.E. Flø, T.F. Næsje, R. Saksgård \& O. Ugedal. 2004. Whitefish fisheries: Abundant resources, but scarce fishermen. Mountain Research and Development, 24: 67-74.

Sandlund, O.T., K. Gunnarson, P.M. Jonasson, B. Jonsson, T. Lindem, K.P. Magnusson, H.J. Malmquist, H. Sigurjonsdottir, S. Skúlason \& S.S. Snorrason. 1992. The arctic charr Salvelinus alpinus (L.) in Thingvallavatn. Oikos, 64: 305-351.

Received: August 2004

Accepted: October 2004
Schluter, D. 1996. Ecological speciation in postglacial fishes. Phil. Trans. the Royal Soc. London. Ser. B Biological Sciences, 351: 807-814.

Sendek, D.S. 2004. The origin of sympatric forms of European whitefish (Coregonus lavaretus (L.)) in Lake Ladoga based on comparative genetic analysis of populations in North-West Russia. Annales Zoologici Fennici, 41: 25-39.

Shaklee, J.B., F.W. Allendorf, D.C. Morizot \& G.S. Whitt. 1990. Gene nomenclature for protein-coding loci in fish. Trans. Am. Fish. Soc., 119: 2-15.

Skúlason, S. \& T.B. Smith. 1995. Resource polymorphisms in vertebrates. Trends in Ecology \& Evolution, 10: 366370.

Skurdal, J., L.A. Vøllestad \& T. Qvenild. 1985. Comparison of scales and otoliths for age determination of whitefish Coregonus lavaretus. Fish. Res., 3: 237-243.

Svärdson, G. 1979. Speciation of Scandinavian Coregonus. Rep. Inst. Freshw. Res. Drottningholm, 57: 3-95.

Swofford, D.L. \& R.B. Selander. 1981. BIOSYS-1: a FORTRAN program for the comprehensive analysis of electrophoretic data in population genetics and systematics. Journal of Heredity, 72: 281-283.

Taylor, E.B. \& P. Bentzen. 1993. Evidence for multiple origins and sympatric divergence of trophic ecotypes of smelt (Osmerus) in northeastern North America. Evolution, 47: 813-832.

Turgeon, J., A. Estoup \& L. Bernatchez. 1999. Species flock in the North American Great Lakes: molecular ecology of Lake Nipigon ciscoes (Teleostei: Coregonidae: Coregonus). Evolution, 53: 1857-1871.

Ugedal, O., T.F. Næsje, R. Saksgård, O.T. Sandlund \& K. Østbye. 2002. Do commercial gill-net fisheries impact polymorphic European whitefish in Lake Femund, Norway? Arch. Hydrobiol. Special Issues Advances in Limnology, 57: 563-576.

Vuorinen, J. 1984. Electrophoretic expression of genetic variation and duplicate gene activity in vendace, Coregonus albula (Salmonidae). Hereditas, 101: 85-96.

Vuorinen, J. \& J. Piironen. 1984. Inheritance and joint segregation of biochemical loci in European whitefish, genus Coregonus. Hereditas, 101: 97-102.

Vuorinen, J., T.F. Næsje \& O.T. Sandlund. 1991. Genetic changes in a vendace, Coregonus albula, population 92 years after introduction. J. Fish Biol. (Suppl. A), 39: 193-201.

Vuorinen, J.A., R.A. Bodaly, J.D. Reist, L. Bernatchez \& J.J. Dodson. 1993. Genetic and morphological differentiation between dwarf and normal size forms of lake whitefish (Coregonus clupeaformis) in Como Lake, Ontario. Can. J. Fish. Aquat. Sci., 50: 210-216.

Vuorinen, J.A., A. Champigneulle, K. Dabrowski, R. Eckmann \& R. Rösch. 1986. Electrophoretic variation in central European coregonid populations. Arch. Hydrobiol. Beiheft, 22: 291-298.

Waples, R.S. 1988. Estimation of allele frequencies at isoloci. Genetics, 118: 371-384.

Weir, B.S. \& C.C. Cockerham. 1984. Estimating F-statistics for the analysis of population structure. Evolution, 38: 1358-1370.

Wright, S. 1978. Evolution and the Genetics of Populations, Vol. 4. Variability Within and Among Natural Populations. University of Chicago Press, Chicago. 